\title{
STUDY OF THE PROTECTIVE ROLE OF OMEGA 3 ON HEPATOTOXICITY INDUCED BY DIFFERENT ENERGY DRINKS IN ADULT MALE ALBINO RATS
}

\author{
Afify $A M^{1}$, Abd El-Wahab $W A^{1}$, Mohammed $A A^{2}$, Abd Al-Rahman $R A^{3}$ and El-Sayed \\ $S B^{1}$ \\ 1 Forensic Medicine and Clinical Toxicology department - Faculty of Medicine for \\ Girls-Al-Azhar University, Egypt. \\ 2 Cell Biology department, National Research centre in Dokki, Egypt. \\ 3 Histology department Faculty of Medicine for Girls, AL-Azhar University, Egypt.
}

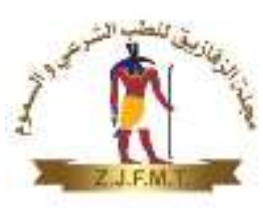

\section{ABSTRACT}

Energy drinks (EDs) became a worldwide phenomenon and popular especially among young adult and the liver is one of the most vulnerable organs to toxicity. The aim of this work was to study the sub chronic effect of consumption of different popular energy drinks (power horse $(\mathrm{PH})$ and red bull $(\mathrm{RB})$ on the liver of adult male albino rats through biochemical and histological parameters and to determine the possible protective role of Omega-3. Also, to determine the effects of their withdrawal (recovery period). Materials and methods: Forty-eight adult male albino rats were divided into 8 groups; control, omega 3, RB, PH, each of EDs combined with omega 3 for 4 weeks followed by other 2 weeks as recovery. Blood samples and liver were obtained from the rats for biochemical and histological evaluation. Results: The studied EDs resulted in elevation of the liver function markers (AST, ALT, ALP and total bilirubin) and reduction of total protein with disturbance in the normal histology of the liver. Either treatment with omega 3 or EDs withdrawal improve these changes with better effect to omega 3. Conclusion: EDs are toxic to the liver. Omega 3 or EDs withdrawal can ameliorate this toxicity. Recommendation: Strict control of EDs consumption is urgently needed.

Key words: Energy drinks, power horse, red bull, liver toxicity.

\section{I- INTRODUCTION}

E nergy drinks are beverages that contain caffeine and other plant-based stimulants, sugars, and other additives which are widely promoted as products that increase alertness and enhance physical and mental performance (NCCIH, 2017). These are commonly available in grocery stores, bars, night clubs, super markets and vending machines, usually displayed alongside soft drinks, juices and sports drinks (Akande and Banjoko, 2011).

The average consumer is attracted by the unusual claims of increased energy, alertness, and sports performance hence they often have catchy names that convey strength, power, speed, sexuality and often include appropriate background music (e.g., Power horse, Red bull, Full throttle, Dare devil, Cocaine e.t.c). Generally speaking, energy drinks are marketed towards young people, such as students staying up all-night while studying, driving long distances or partying (Malinauskas et al., 2007).

Energy drinks are typically attractive to young people. Approximately $65 \%$ of its consumers are between the ages of 13 and 35 years old, with males two thirds of the market
(Akande and Banjoko, 2011). Serious adverse effects of energy drinks have especially been linked to children, adolescents, and young adults (Seifert et al., 2011).

Omega-3 fatty acids ( $\omega 3$ FAs) are considered essential fatty acids. They are highly important to human health. Extensive researches indicated that $\omega 3$ FAs are considered as strong antioxidants and found to play protective roles in the liver, cardiovascular and kidney diseases (Abdou and Hassan, 2014).

As the popularity of energy drinks continues to rise, there is a genuine concern among the health professionals and authorities regarding the negative health impact of these products (Alabbad et al., 2019). There are few studies on the effects of the energy drinks on various systems of the body (Mohamed et al., 2018). The liver is the major site of metabolism, including detoxification and activation of many substances (Emam et al., 2018). Therefore, the aim of the present study was to study the sub chronic effect of consumption of different popular energy drinks (power horse and red bull) on liver after oral administration in adult male albino 
rats through biochemical and histological parameters and to determine the possible protective role of Omega-3. Also, to determine the effect of a recovery period (stopping administration of energy drinks).

\section{II- MATERIALS AND METHODS}

\section{1.Place of the study:}

- Faculty of Medicine for Girls Al-Azhar University: Handling of animals and histopathological studies.

- National Research Center in Dokki (Cairo): Biochemical studies.

\section{II.2.Chemicals:}

- The Power horse and red bull EDs were bought from a local market.

- Omega-3 ( $\omega 3)$ used in this study was in the form of fish oil-containing gelatinous capsules, called Omega- 300 capsules was manufactured by The Arab Co. for Gelatin and Pharmaceutical products for Montana Pharmaceutical. Each capsule contains 1000 mg fish oil (fish oil contains 30\% omega 3, (Soliman et al., 2010)) and was evacuated by syringe carefully and given to rats by oral gavage.

- All reagents used in this study were of analytical grade and were purchased from Sigma-Aldrich Chemie GmbH, Germany.

\section{II.3.Experimental animals:}

Forty eight adult male albino rats, weighting $150 \pm 10 \mathrm{gm}$ were obtained from Helwan animal breeding farm, Cairo, Egypt, they were conditioned in standard metallic cages (6 rats per cage) and kept under the same environmental conditions regarding light, feeding and temperature with an alternating $12 \mathrm{~h}$ light - dark cycle. They were acclimatized to the laboratory conditions, fed standard rat chow and water was available ad libitum.

The handling of animals followed the rules for the experimental research ethics approved by Research Ethics Committee at faculty of Medicine for Girls Al-Azhar University.

The animals were divided into 8 groups of 6 rats each and treated as follows:

*Group 1 (control group): Normal healthy animals were received distillate water orally ad libitum for 4 weeks.

*Group 2 (omega 3 group): Rats were given omega- 3 by gavage, at a dose of $300 \mathrm{mg} / \mathrm{kg}$ once daily for 4 weeks (Ayuob and ElBeshbeishy, 2016)

*Group 3 (PH group): Rats were given power horse energy drink with oral dose $(1.5 \mathrm{ml} / 100 \mathrm{gm} /$ day) once daily for 4 weeks (Khayyat et al., 2014).

*Group 4 (PH+ recovery period group): Rats were given power horse energy drink with oral dose $(1.5 \mathrm{ml} / 100 \mathrm{gm} /$ day $)$ once daily for 4 weeks (Khayyat et al., 2014), these rats will be kept on normal diet only for another 2 weeks (for recovery).

*Group 5 (PH+ omega-3 group): Rats were administered power horse energy drink+ omega-3 with oral dose $(1.5 \mathrm{ml} / 100 \mathrm{gm} /$ day, $300 \mathrm{mg} / \mathrm{kg} /$ day) respectively once daily for 4 weeks (Khayyat et al., 2014; Ayuob and ElBeshbeishy, 2016).

*Group 6 (RB group): Rats were given red bull energy drink with oral dose $(1.5 \mathrm{ml} / 100 \mathrm{gm} /$ day $)$ once daily for 4 weeks (Khayyat et al., 2014).

*Group 7 ( $\mathbf{R B}+$ recovery period group): Rats were given red bull energy drink with oral dose $(1.5 \mathrm{ml} / 100 \mathrm{gm} /$ day $)$ once daily for 4 weeks (Khayyat et al., 2014), then rats will be kept on normal diet only for another 2 weeks (for recovery).

*Group 8 (RB+ omega-3 group): Rats were administered red bull energy drink+ omega-3 with oral dose $(1.5 \mathrm{ml} / 100 \mathrm{gm} /$ day, 300 $\mathrm{mg} / \mathrm{kg}$ /day) respectively once daily for 4 weeks (Khayyat et al., 2014; Ayuob and ElBeshbeishy, 2016).

\section{II.4.Specimens collection:}

a) Twenty-four hours after the last dose of treatment, all animals were lightly anaesthetized with diethyl ether inhalation. Blood samples were obtained from the retro orbital sinus puncture into heparinized capillary tubes from each rat before killing. Blood samples were collected in clean dry test tubes and centrifuged at $2000 \mathrm{rpm}$ for 15 minutes. Sera were then separated and kept frozen at $-20{ }^{\circ} \mathrm{C}$ for estimation of the studied liver function markers.

b) After collecting blood samples, animals were sacrificed by cervical dislocation while they were under anesthesia. Liver was dissected immediately for histopathological studies.

II.5.Biochemical studies: 


\section{Liver function markers}

- Aspartate aminotransferase (AST) and Alanine aminotransferase (ALT): According to the International Federation of Clinical Chemistry (IFCC), (1980).

- Alkaline phosphatase (ALP): According to Keiding et al., (1974).

- Total bilirubin: According to Walter and Gerad, (1970).

- total protein in the serum: According to Bradford, (1976).

\section{II.6.Histopathological studies:}

Liver specimens were fixed using $10 \%$ neutral buffered formaldehyde. After proper fixation, the specimens were dehydrated in ascending grades of ethyl alcohol $(70 \%, 90 \%$, $100 \%$ ), cleared in xylol, impregnated and then embedded in paraffin wax. 5- $\mu$ m thick sections were cut using rotatory microtome. Liver sections were stained with routine haematoxylin and eosin (H\&E) stain as a routine stain for studying the general histological structure of the brain (Kieranan, 1999).

\section{II.7.Statistical analysis:}

Data were analyzed using Statistical Program for Social Science (SPSS) version
(20). All data were presented as mean standard deviation (SD). For statistical analysis of the effects of different treatments, independent $\mathrm{T}$ - test was done $\mathrm{P}$-value $\leq 0.05$ was considered significant.

\section{III-RESULTS}

\section{III.1. Biochemical results}

\section{*AST, ALT, ALP and total bilirubin}

There were no statistically significant difference $(p>0.05)$ between the control group and $\omega 3$ group as regards the studied liver function markers (AST, ALT, ALP and total bilirubin). But, there were a statistically significant increase in serum level of the studied liver function markers in (power horse) and (red bull) groups as compared to the control group. Subchronic toxicity with (power horse) energy drink showed more increase in the serum levels of AST, ALT and ALP than (red bull) energy drink. A statistically significant decrease in serum levels of the studied liver function markers in recovery and $\omega 3$ groups as compared to power horse and red bull groups. Treatment with $\omega 3$ showed more reduction in the serum level of the studied liver function markers than the recovery period (Tables 1,2 ).

Table (1): comparison between the eight studied groups as regards AST and ALT activities in the serum of adult male albino rats using independent T- test.

\begin{tabular}{|c|c|c|c|c|}
\hline \multirow{2}{*}{$\begin{array}{c}\text { Groups } \\
\mathrm{n}=6 \text { rats/group }\end{array}$} & \multicolumn{2}{|c|}{ AST (IU/L) } & \multicolumn{2}{|l|}{ ALT (IU/L) } \\
\hline & Mean \pm SD & $p$ value & Mean \pm SD & $\mathrm{p}$ value \\
\hline Control group & $50.2 \pm 0.95$ & - & $52.3 \pm 1.13$ & - \\
\hline$\omega 3$ group & $50.1 \pm 1$ & $0.84^{\mathrm{a}}$ & $52.1 \pm 1.18$ & $0.7^{\mathrm{a}}$ \\
\hline PH group & $84.4 \pm 1.1$ & $\leq 0.05^{\mathrm{a}^{*}}$ & $100.1 \pm 1.51$ & $\leq 0.000^{\mathrm{a}^{* *}}$ \\
\hline \multirow{2}{*}{$\begin{array}{l}\mathrm{PH}+\text { recovery } \\
\text { period group }\end{array}$} & \multirow[t]{2}{*}{$56.5 \pm 1.8$} & $\leq 0.000^{\mathrm{a}^{* * *}}$ & \multirow[t]{2}{*}{$58.4 \pm 1.7$} & $\leq 0.000^{\mathrm{a}^{* * *}}$ \\
\hline & & $\leq 0.05^{\mathrm{b}^{*}}$ & & $\leq 0.000^{b^{* *}}$ \\
\hline \multirow[t]{3}{*}{$\mathrm{PH}+\omega 3$ group } & \multirow[t]{3}{*}{$54.3 \pm 0.87$} & $\leq 0.000^{\mathrm{a}^{\mathrm{a} *}}$ & \multirow[t]{3}{*}{$55.1 \pm 1.04$} & $\leq 0.000^{\mathrm{a}^{* *}}$ \\
\hline & & $\leq 0.05^{\mathrm{b}^{*}}$ & & $\leq 0.000^{\mathrm{b}^{* *}}$ \\
\hline & & $0.01^{\mathrm{d}^{* *}}$ & & $0.001^{\mathrm{d}^{* * *}}$ \\
\hline \multirow{2}{*}{ RB group } & \multirow[t]{2}{*}{$81.2 \pm 0.99$} & $\leq 0.05^{a^{*}}$ & \multirow[t]{2}{*}{$95.7 \pm 2.8$} & $\leq 0.000^{\mathrm{a}^{* * *}}$ \\
\hline & & $\leq 0.000^{b^{* *}}$ & & $0.003^{b^{* *}}$ \\
\hline \multirow{2}{*}{$\begin{array}{l}\text { RB+ recovery } \\
\text { period group }\end{array}$} & \multirow[t]{2}{*}{$54.3 \pm 1.1$} & $\leq 0.000^{\mathrm{a}^{* * *}}$ & \multirow[t]{2}{*}{$57.6 \pm 1.7$} & $\leq 0.000^{\mathrm{a}^{* * *}}$ \\
\hline & & $\leq 0.000^{\mathrm{c}^{* * *}}$ & & $\leq 0.000^{\mathrm{c} * *}$ \\
\hline \multirow[t]{3}{*}{$\mathrm{RB}+\omega 3$ group } & \multirow[t]{3}{*}{$53.4 \pm 1$} & $\leq 0.000^{\mathrm{a}^{* * *}}$ & \multirow[t]{3}{*}{$54.8 \pm 1.005$} & $0.001^{\mathrm{a}^{* *}}$ \\
\hline & & $\leq 0.000^{\mathrm{c}^{* * /}}$ & & $\leq 0.000^{\mathrm{c}^{* * *}}$ \\
\hline & & $0.8^{\mathrm{e}}$ & & $0.003^{\mathrm{e}^{* *}}$ \\
\hline
\end{tabular}

$\mathbf{S D}=$ standard deviation, $\mathrm{PH}=$ power horse, $\mathrm{RB}=$ red bull, $\mathbf{\omega 3}=$ omega 3 . $\mathrm{a}=$ compared with control group, $\quad b=$ compared with $\mathrm{PH}$ group, $\mathrm{c}=$ compared with $\mathrm{RB}$ group, $\mathrm{d}=$ compared with $\mathrm{PH}+$ 
recovery period group, $\mathrm{e}=$ compared with $\mathrm{RB}+$ recovery period group. $\mathrm{P} \leq 0.05$ was considered to be significant $=*, \mathrm{P} \leq 0.01$ was considered to be highly significant, $=* *$

Table (2): comparison between the eight studied groups as regards the levels of ALP and total bilirubin in the serum of adult male albino rats using independent $\mathrm{T}$ - test.

\begin{tabular}{|c|c|c|c|c|}
\hline \multirow{2}{*}{$\begin{array}{l}\text { Groups } \\
\mathrm{n}=6 \text { rats/ } \\
\text { group }\end{array}$} & \multicolumn{2}{|l|}{ ALP (IU/L) } & \multicolumn{2}{|c|}{ Total bilirubin (mg/dl) } \\
\hline & Mean \pm SD & $\mathrm{p}$ value & Mean \pm SD & $\mathrm{p}$ value \\
\hline Control group & $149.9 \pm 0.92$ & - & $0.27 \pm 0.01$ & - \\
\hline$\omega 3$ group & $149.6 \pm 0.99$ & $0.67^{\mathrm{a}}$ & $0.26 \pm 0.01$ & $0.3^{\mathrm{a}}$ \\
\hline PH group & $532.7 \pm 26.6$ & $\leq 0.000^{\mathrm{a}^{* *}}$ & $1.4 \pm 0.32$ & $\leq 0.000^{\mathrm{a}^{* *}}$ \\
\hline \multirow{2}{*}{$\begin{array}{l}\mathrm{PH}+\text { recovery } \\
\text { period group }\end{array}$} & \multirow{2}{*}{$184.3 \pm 2.8$} & $\leq 0.000^{\mathrm{a}^{* *}}$ & \multirow{2}{*}{$0.39 \pm 0.016$} & $<0.000^{\mathrm{a}^{* * *}}$ \\
\hline & & $\leq 0.000^{b^{* *}}$ & & $\leq 0.000^{\mathrm{b}^{* *}}$ \\
\hline \multirow[t]{3}{*}{$\mathrm{PH}+\omega 3$ group } & \multirow[t]{3}{*}{$163 \pm 2.1$} & $\leq 0.000^{\mathrm{a}^{* *}}$ & \multirow[t]{3}{*}{$0.31 \pm 0.016$} & $\leq 0.000^{\mathrm{a}^{* *}}$ \\
\hline & & $\leq 0.000^{\mathrm{b}^{* *}}$ & & $\leq 0.000^{\mathrm{b}^{* *}}$ \\
\hline & & $\leq 0.000^{\mathrm{d}^{* *}}$ & & $\leq 0.000^{\mathrm{d}^{* *}}$ \\
\hline \multirow[t]{2}{*}{ RB group } & \multirow[t]{2}{*}{$464.7 \pm 26.7$} & $\leq 0.000^{\mathrm{a}^{* *}}$ & \multirow[t]{2}{*}{$1.2 \pm 0.18$} & $\leq 0.000^{\mathrm{a}^{* *}}$ \\
\hline & & $\leq 0.000^{b^{* *}}$ & & $0.2^{b}$ \\
\hline \multirow{2}{*}{$\begin{array}{l}\mathrm{RB}+\text { recovery } \\
\text { period group }\end{array}$} & \multirow[t]{2}{*}{$170.6 \pm 2.5$} & $\leq 0.000^{\mathrm{a}^{* *}}$ & \multirow[t]{2}{*}{$0.35 \pm 0.02$} & $\leq 0.000^{\mathrm{a}^{* *}}$ \\
\hline & & $\leq 0.000^{\mathrm{c}^{* *}}$ & & $\leq 0.000^{\mathrm{c}^{* *}}$ \\
\hline \multirow[t]{3}{*}{$\mathrm{RB}+\omega 3$ group } & \multirow[t]{3}{*}{$159 \pm 1.8$} & $\leq 0.000^{\mathrm{a}^{* *}}$ & \multirow[t]{3}{*}{$0.3 \pm 0.004$} & $0.003^{a^{* * k}}$ \\
\hline & & $\leq 0.000^{\mathrm{c}^{* *}}$ & & $\leq 0.000^{\mathrm{c}^{* *}}$ \\
\hline & & $\leq 0.000^{\mathrm{e}^{* *}}$ & & $\leq 0.000^{\mathrm{e}^{* *}}$ \\
\hline
\end{tabular}

$\mathbf{S D}=$ standard deviation, $\mathbf{P H}=$ power horse, $\mathbf{R B}=$ red bull, $\mathbf{\omega 3}=$ omega 3 , a= compared with control group, $\mathrm{b}=$ compared with $\mathrm{PH}$ group, $\mathrm{c}=$ compared with $\mathrm{RB}$ group, $\mathrm{d}=$ compared with $\mathrm{PH}+$ recovery period group, $\mathrm{e}=$ compared with $\mathrm{RB}+$ recovery period group.

$\mathrm{P} \leq 0.05$ was considered to be significant $=, \mathrm{P} \leq 0.01$ was considered to be highly significant, $=* *$

\section{*Total protein in serum}

There was no statistically significant difference between the control group and $\omega 3$ group regards to total serum protein. But, there were statistically significant decrease in serum protein level in all other treated groups as compared to control group (group 1). Subchronic toxicity with (power horse) energy drink showed more decrease in the serum protein level than (red bull) energy drink. Statistically highly significant $(\mathrm{P} \leq$ 0.000 ) increase in serum protein levels was noticed in the recovery and $\omega 3$ groups as compared to power horse and red bull groups. Treatment with $\omega 3$ resulted in more increase in the serum level of protein than the recovery period

(Figure, 


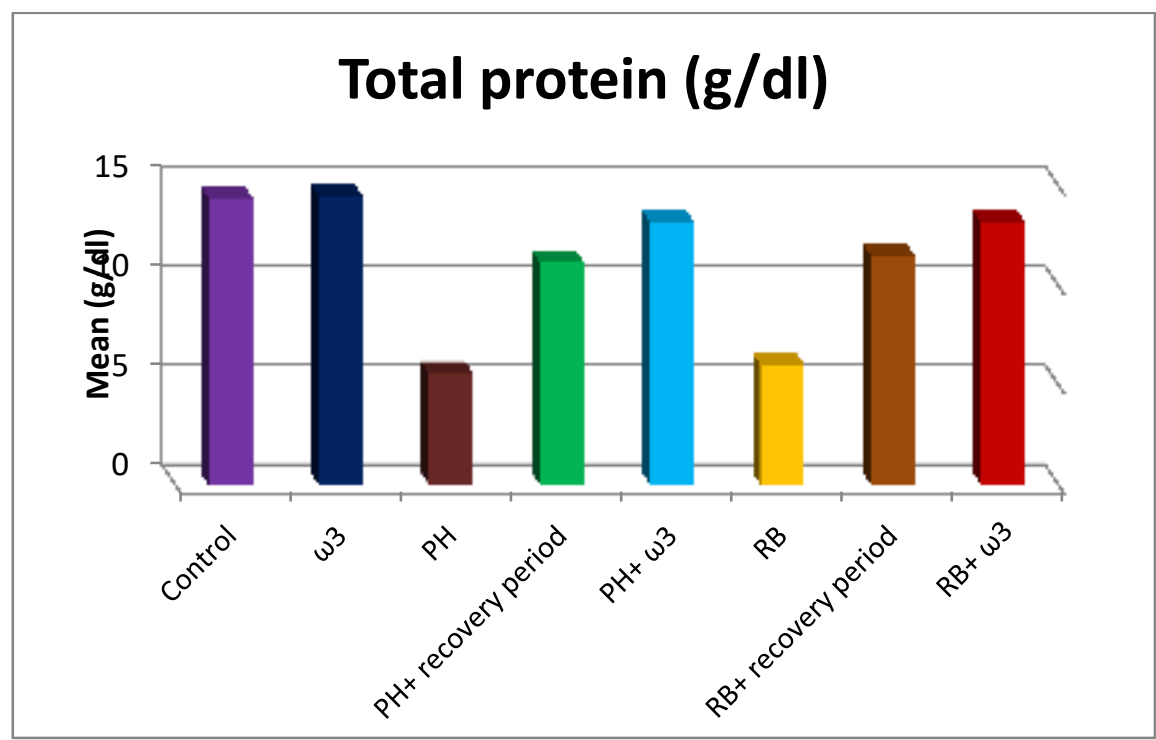

Fig. (1): Histogram shows comparison between the eight studied groups as regards the level of total protein in the serum of adult male albino rats.

\section{III.2.Histopathological results of liver tissues stained with H\&E:}

The control and $(\omega 3)$ groups showed normal histological structure of liver tissue with hepatic cords radiating from the central vein forming anastomosing plates separated by blood sinusoids. Hepatocytes were polyhedral with eosinophilic cytoplasm and central rounded vesicular nuclei (fig. 2,3,4).

In power horse and red bull groups all hepatocytes are vacuolated with small darkly stained nuclei. Also, there is dilated and congested blood vessel and marked mononuclear cellular infiltration in portal tract area. The central vein appears congested (fig.5,6, 9,10).
In the recovery groups (group 4, 7) there was no improvement in the hepatic tissue. The hepatocytes are vacuolated with small darkly stained nuclei. Also, there is dilated and congested blood vessel and marked mononuclear cellular infiltration in portal tract area (fig. 7,11 ).

In ( $\omega 3)$ groups (group 5,8) there was moderate improvement in the hepatic tissue. The hepatocytes are polyhedral with eosinophilic cytoplasm having central rounded and vesicular nuclei. There is marked mononuclear cellular infiltration in portal tract area (fig.8, 12). 


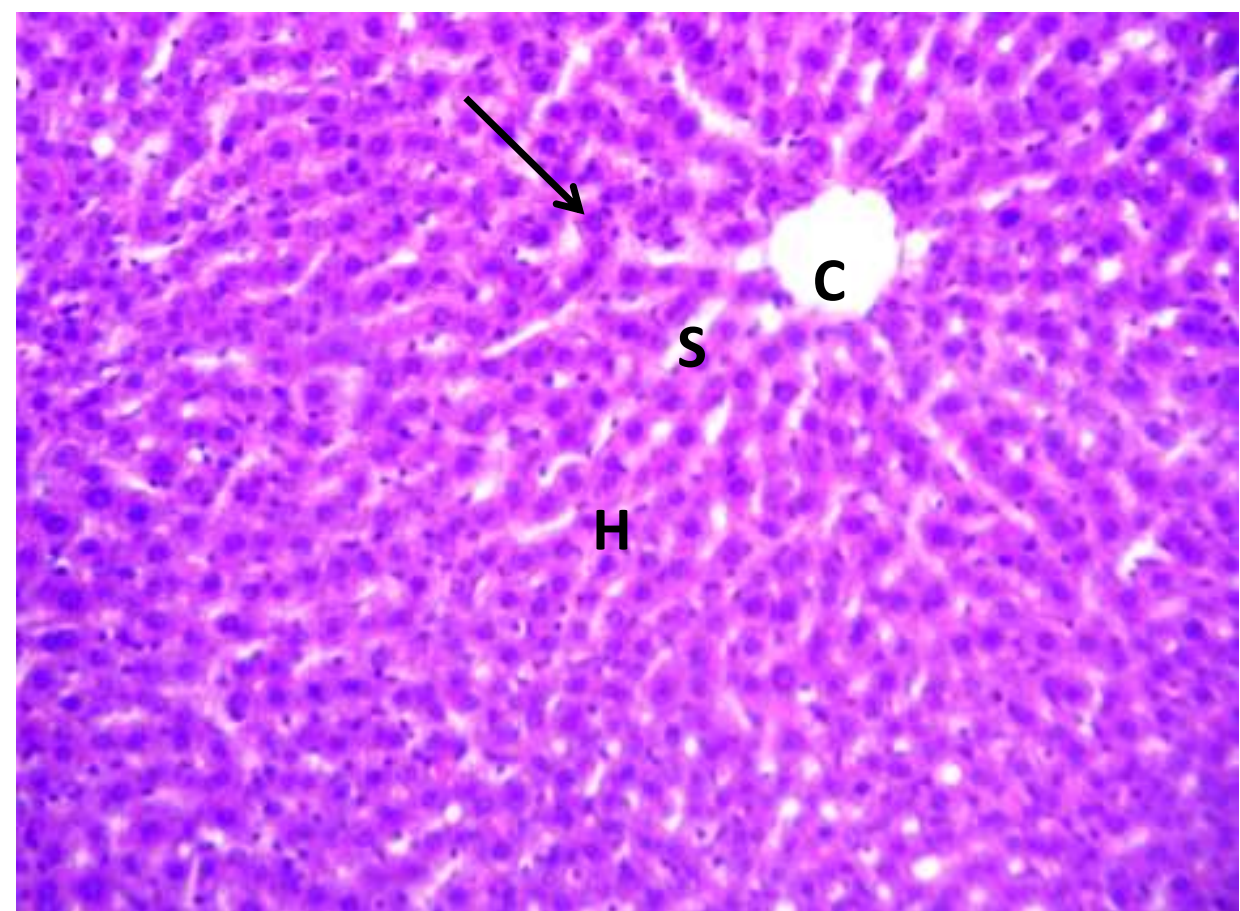

Fig.(2): A photomicrograph of a liver section of an adult albino rat control group, showing that the liver tissue has normal histological structure with hepatic cords $(\mathrm{H})$ radiating from the central vein (C) forming anastomosing plates separated by blood sinusoids (S). Hepatocytes are polyhedral with eosinophilic cytoplasm having central rounded and vesicular nuclei (arrow). (H\&E X 200).

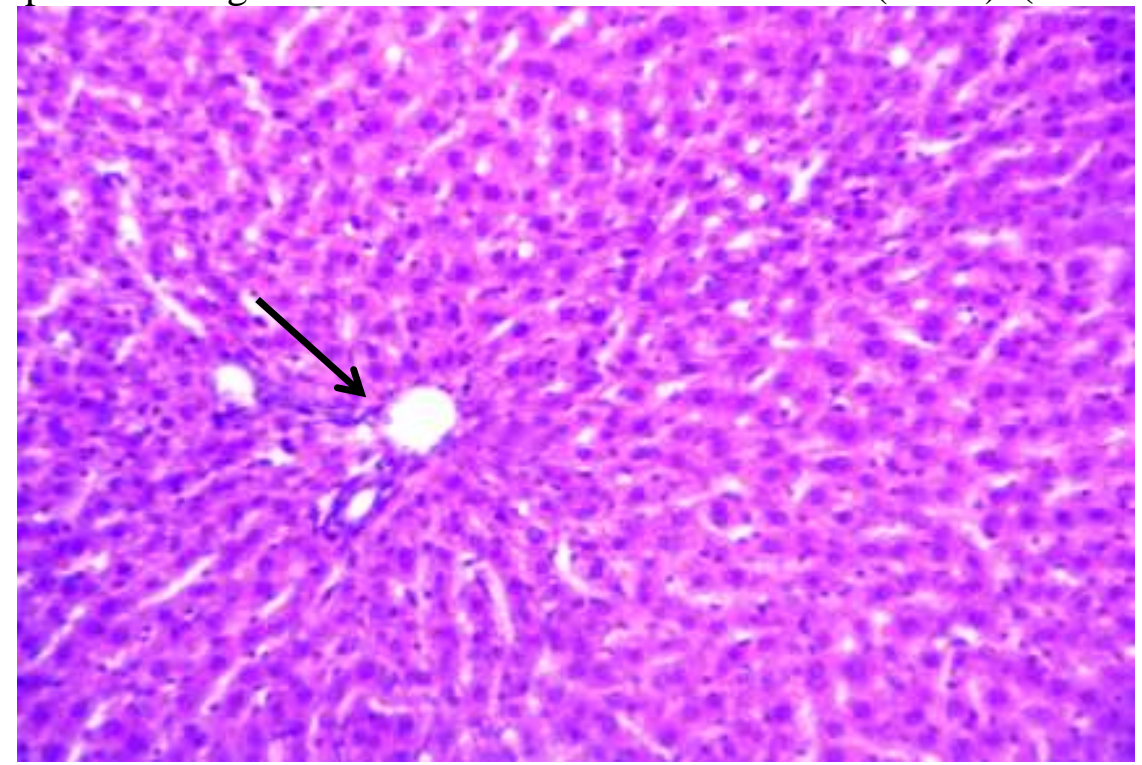

Fig.(3): A photomicrograph of a liver section of an adult albino rat control group, showing the portal tract area (arrow). (H\&E X 200). 


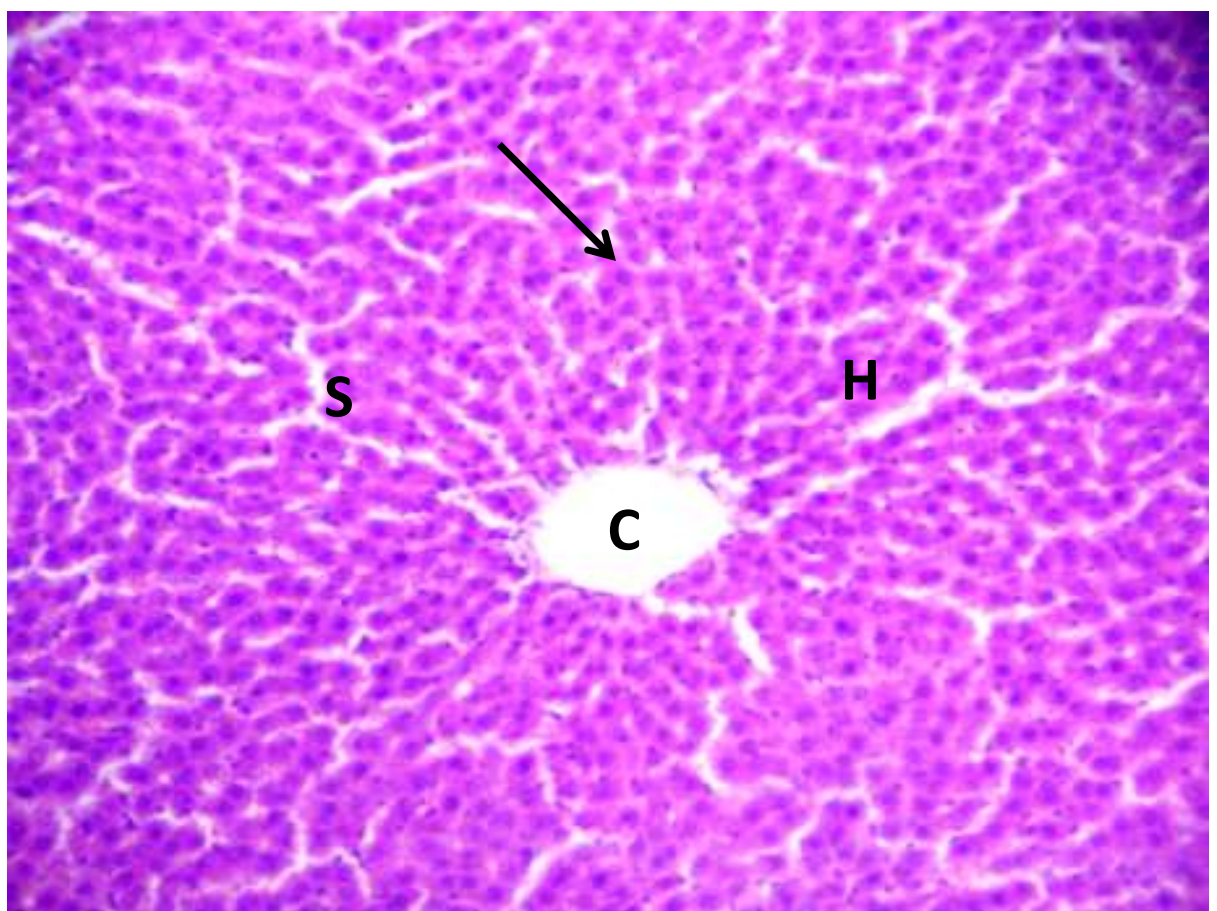

Fig.(4): A photomicrograph of a liver section of an adult albino rat $\boldsymbol{\omega} \mathbf{3}$ group, showing that the liver tissue has normal histological structure with hepatic cords $(\mathrm{H})$ radiating from the central vein $(\mathrm{C})$ forming anastomosing plates separated by blood sinusoids (S). Hepatocytes are polyhedral with eosinophilic cytoplasm having central rounded and vesicular nuclei (arrow). (H\&E X 200).

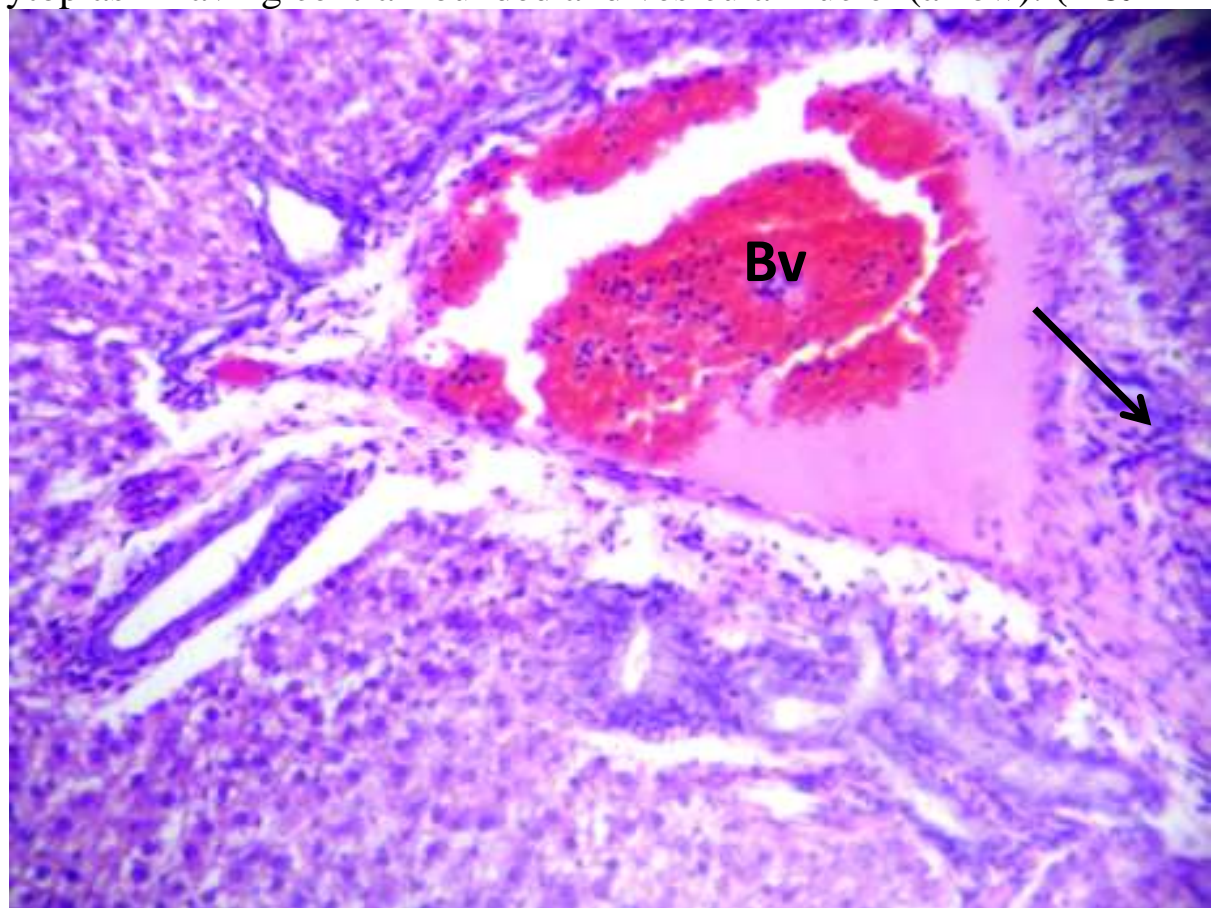

Fig.(5): A photomicrograph of a liver section of an adult male albino rat $\mathrm{PH}$ group, showing the portal tract area with mononuclear cellular infiltration (arrow) and dilated congested blood vessel (Bv) (H\&E X 200). 


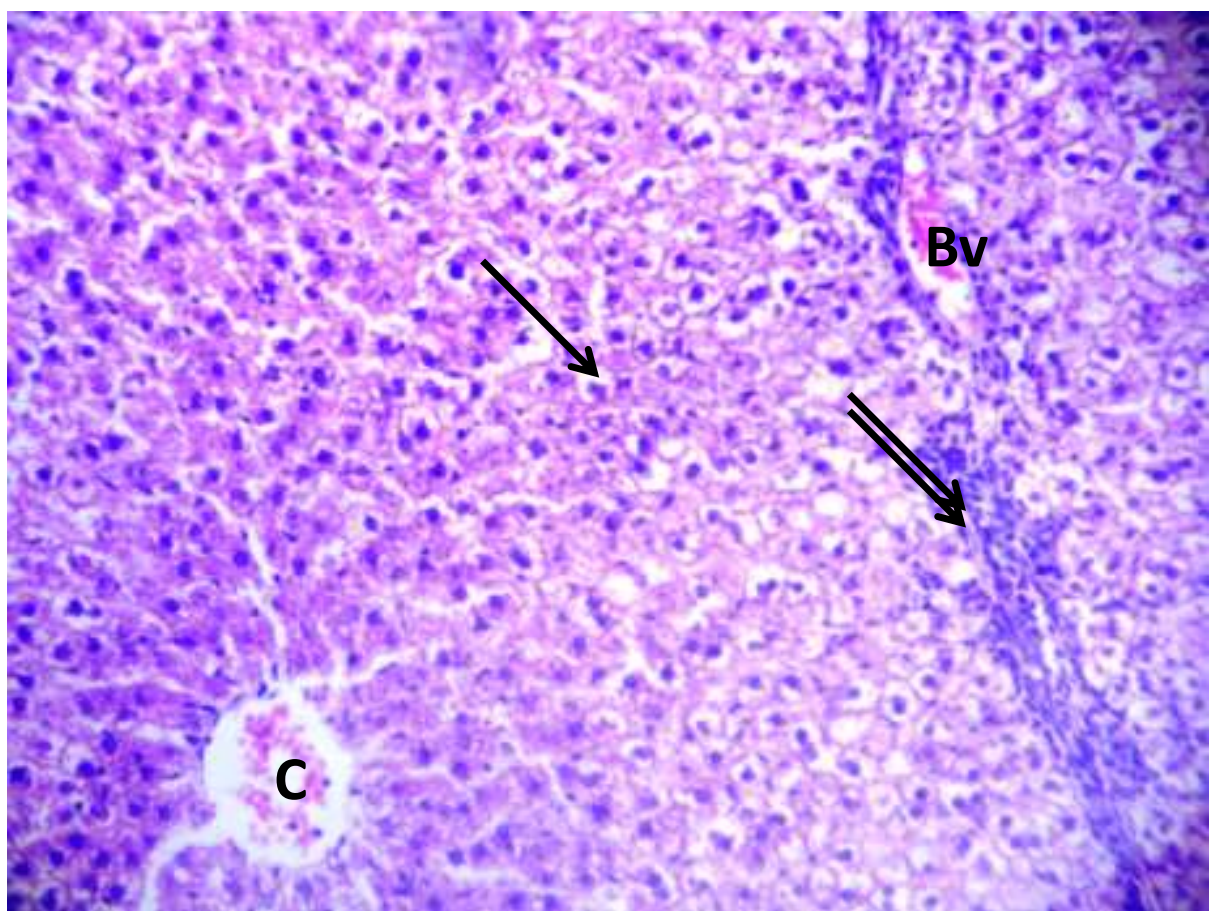

Fig.(6): A photomicrograph of a liver section of an adult male albino rat $\mathrm{PH}$ group, showing that all hepatocytes are vacuolated with small darkly stained nuclei (arrow). Also, there is dilated and congested blood vessel (Bv) and marked mononuclear cellular infiltration (double arrows) in portal tract area. The central vein $(C)$ appears congested (H\&E X 200).

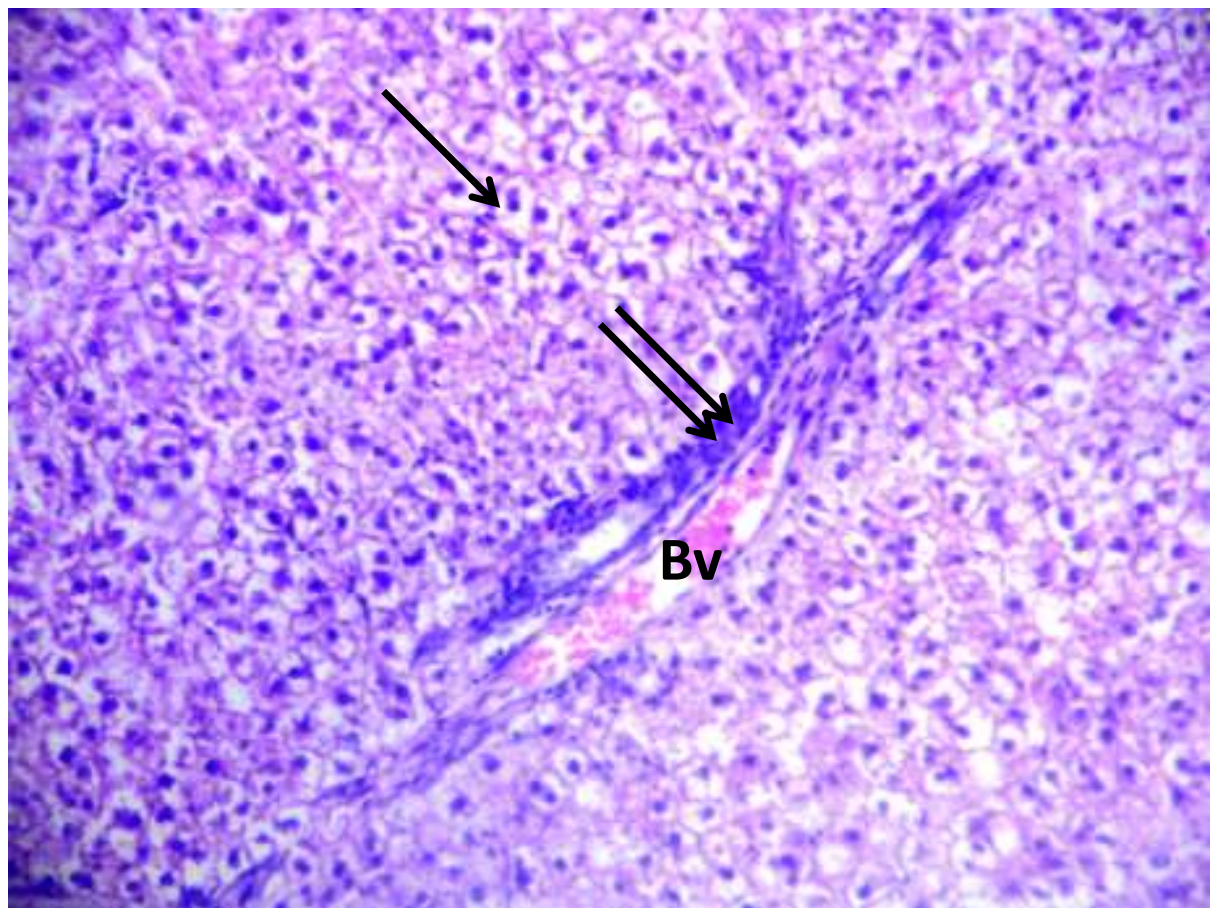

Fig.(7): A photomicrograph of a liver section of an adult male albino rat $\mathrm{PH}+$ recovery group, showing no improvement. The hepatocytes are vacuolated with small darkly stained nuclei (arrow). Also, there is dilated and congested blood vessel $(\mathrm{Bv})$ and marked mononuclear cellular infiltration (double arrows) in portal tract area. (H\&E X 200). 


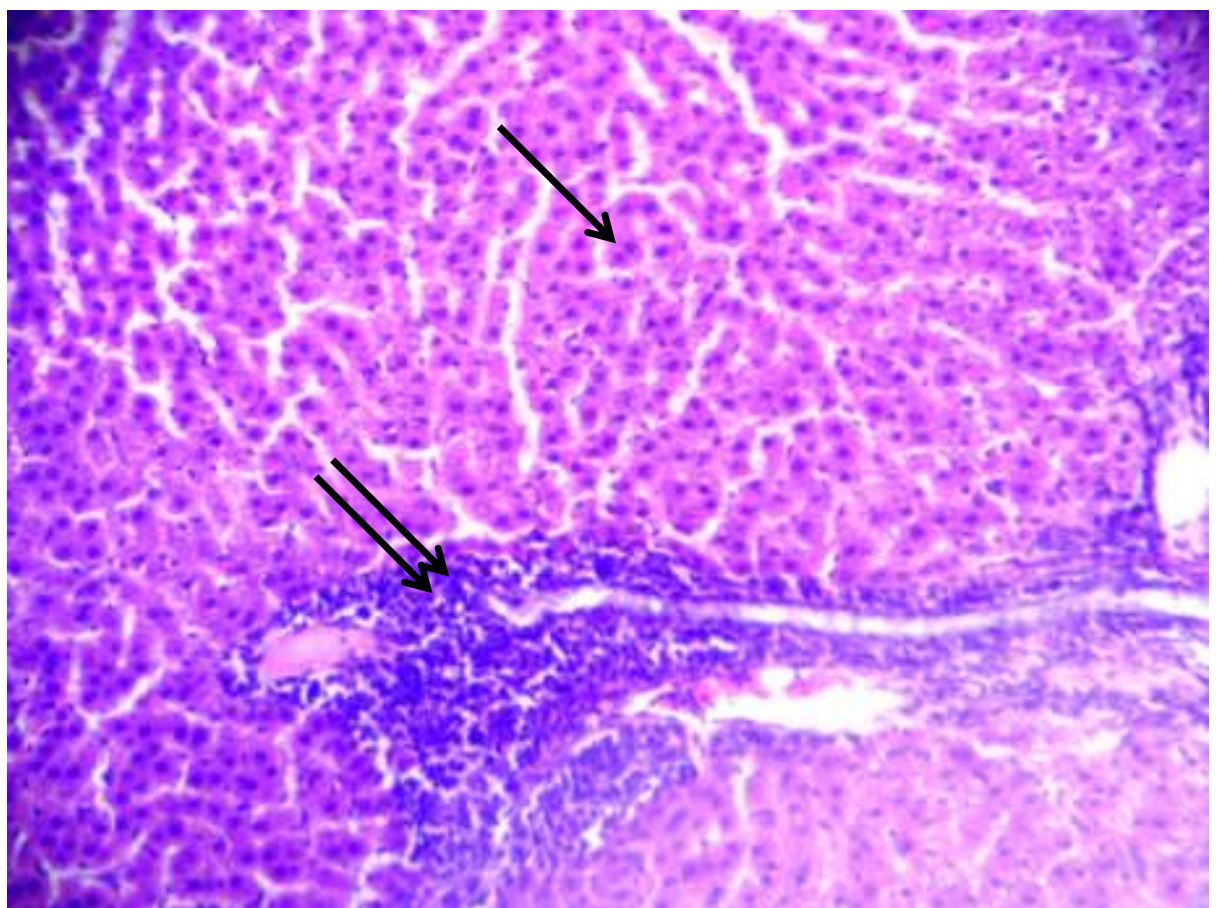

Fig.(8): A photomicrograph of a liver section of an adult male albino rat $\mathrm{PH}+\boldsymbol{\omega} \mathbf{3}$ group showing moderate improvement. The hepatocytes are polyhedral with eosinophilic cytoplasm having central rounded and vesicular nuclei (arrow). There is marked mononuclear cellular infiltration (double arrows) in portal tract area. (H\&E X 200).

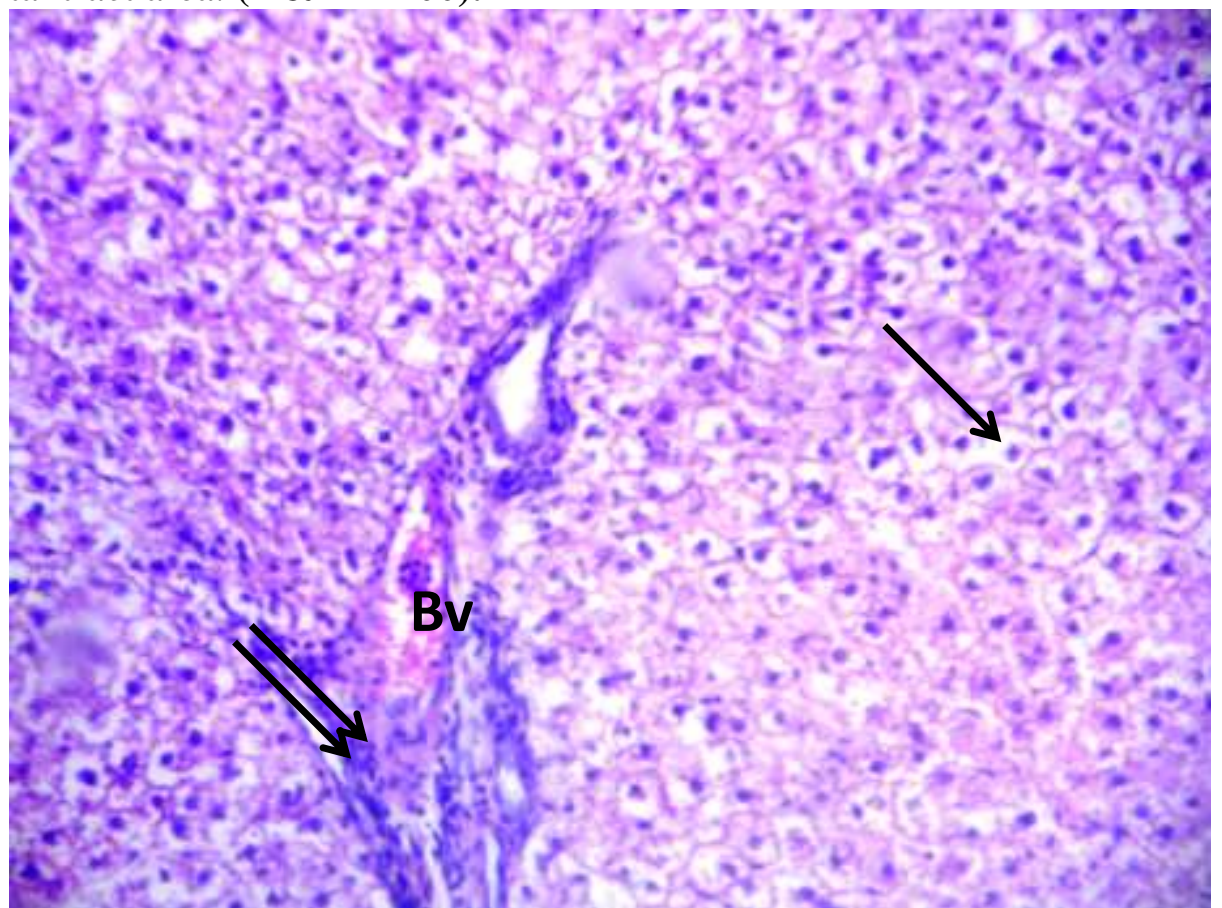

Fig.(9): A photomicrograph of a liver section of an adult male albino rat RB group, showing that all hepatocytes are vacuolated with small darkly stained nuclei (arrow). Also, there is congested blood vessel (Bv) and mononuclear cellular infiltration (double arrows) in portal tract area. (H\&E X 200). 


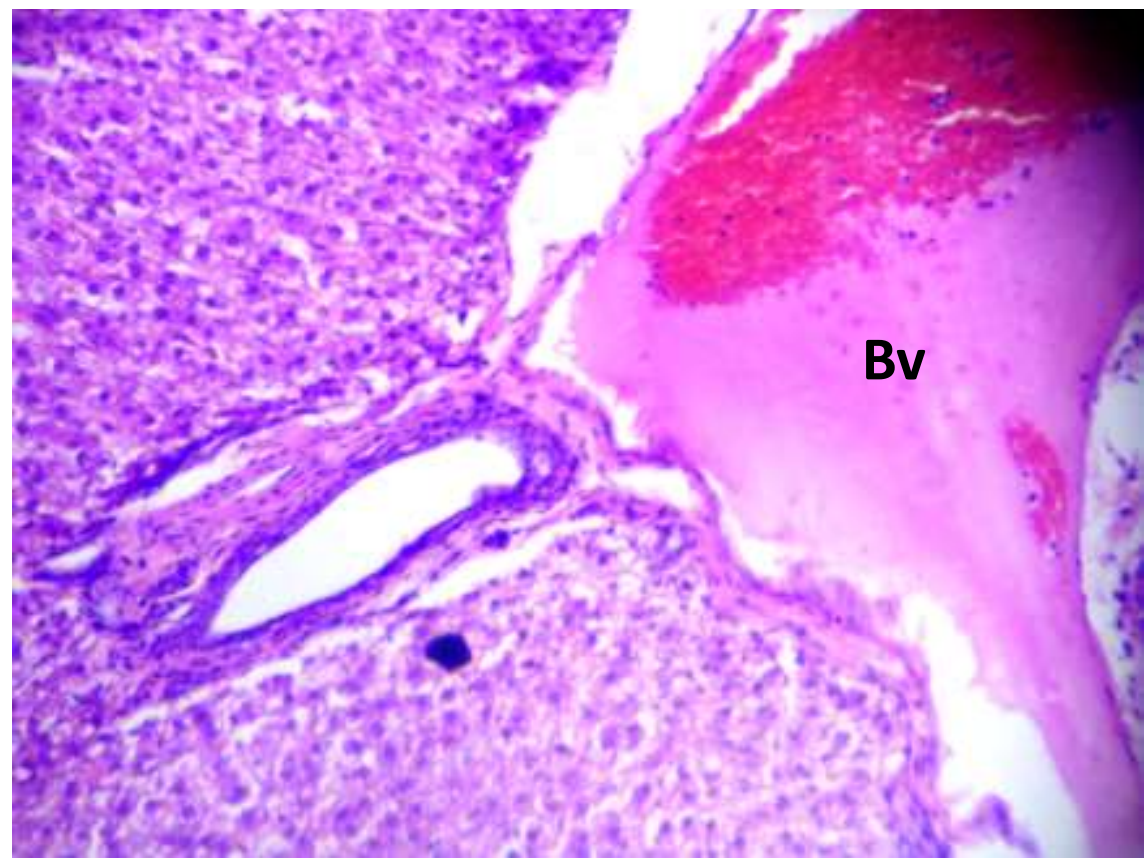

Fig.(10): A photomicrograph of a liver section of an adult male albino rat RB group, showing the portal tract area with dilated congested blood vessel (Bv) (H\&E X 200).

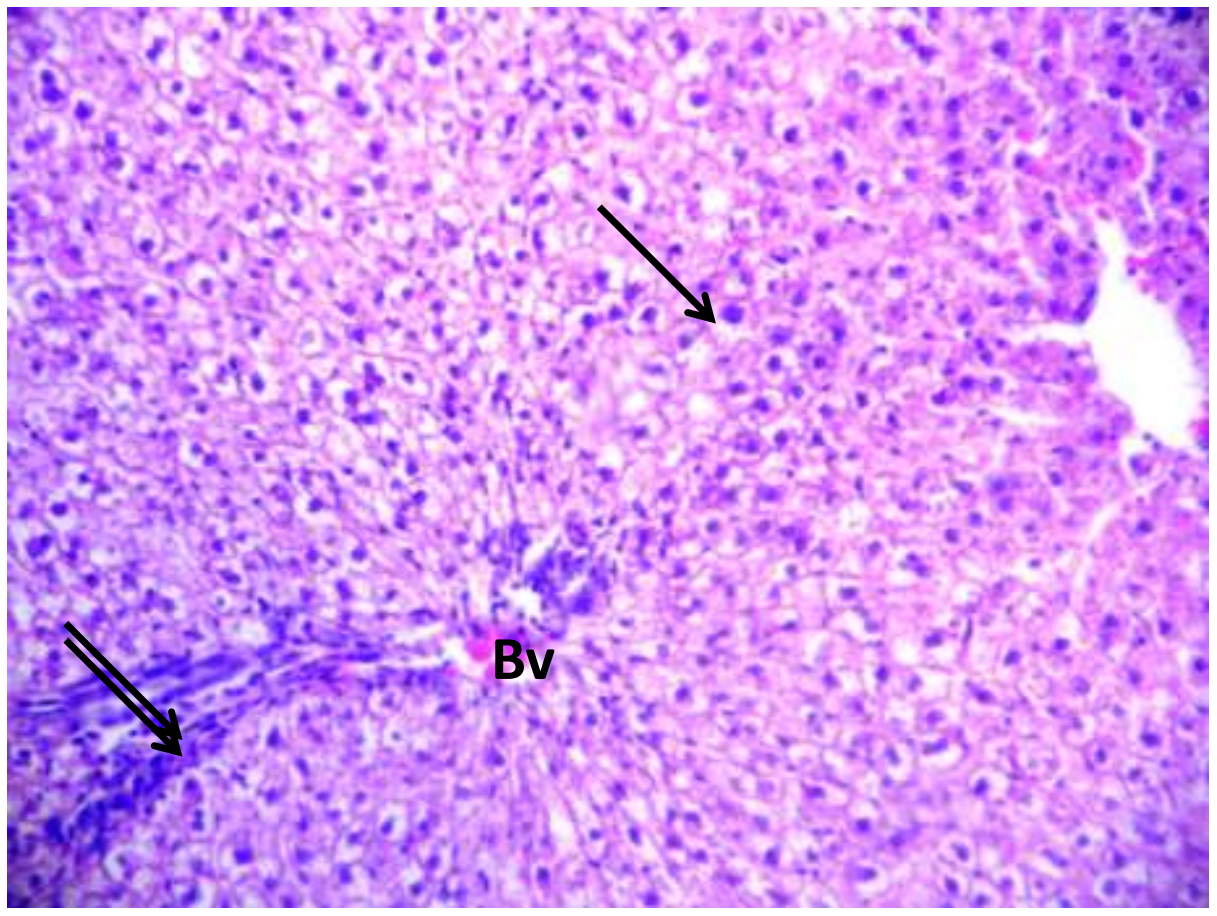

Fig.(11): A photomicrograph of a liver section of an adult male albino rat RB+recovery period group, showing no improvement. The hepatocytes are vacuolated with small darkly stained nuclei (arrow). Also, there is congested blood vessel $(\mathrm{Bv})$ and mononuclear cellular infiltration (double arrows) in portal tract area. (H\&E X 200). 


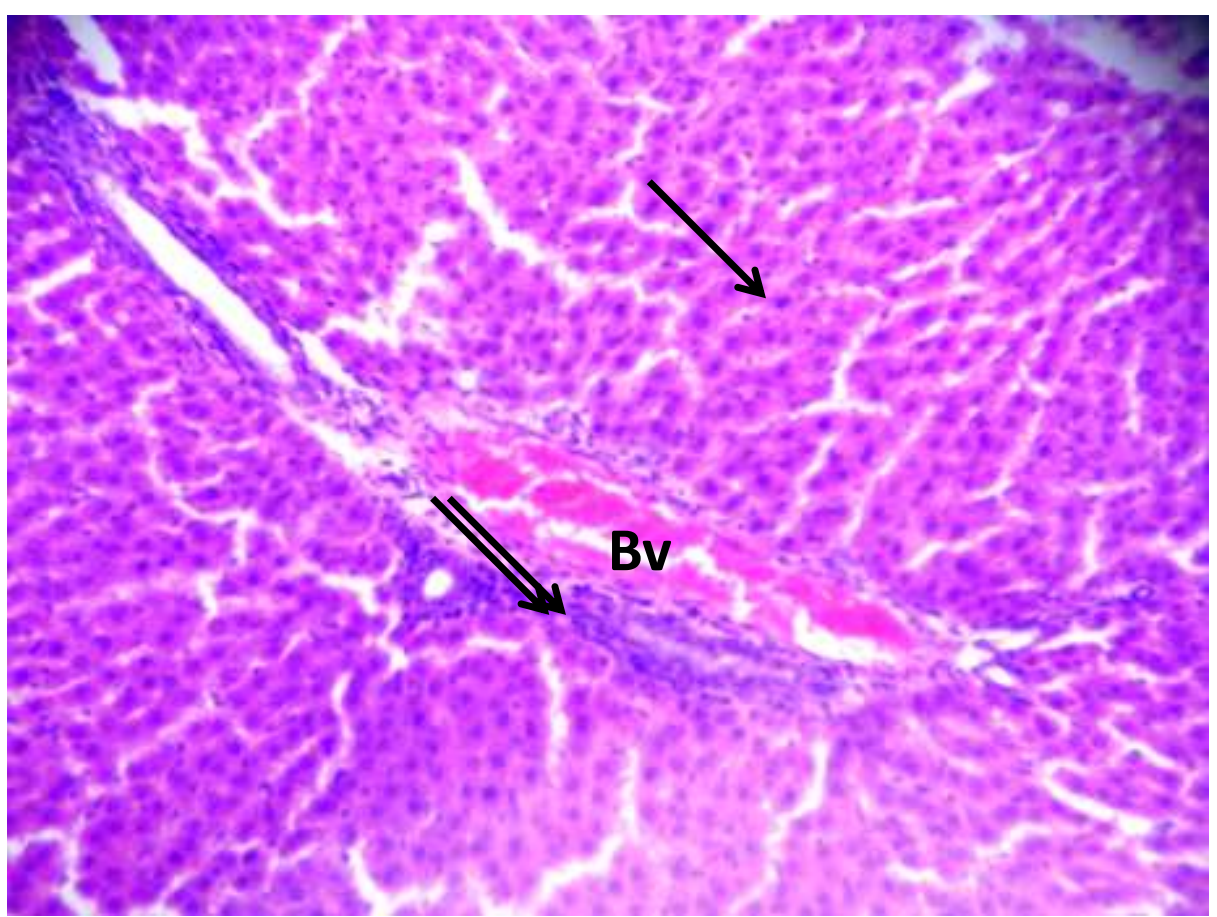

Fig.(12): A photomicrograph of a liver section of an adult male albino rat $\mathrm{RB}+\boldsymbol{\omega} \mathbf{3}$ group showing moderate improvement. The hepatocytes are polyhedral with eosinophilic cytoplasm having central rounded and vesicular nuclei (arrow). There is marked mononuclear cellular infiltration (double arrows) in portal tract area. Also, dilated and congested blood vessel (Bv) can be seen (H\&E X 200).

Beverages marketed as "energy drinks" contain stimulants, mainly caffeine and are marketed with the claims that they are mental and physical stimulants (Alabbad et al., 2019). Previous studies demonstrated histopathological lesions in different organs following administration of energy drinks. These organs include liver (Khayyat et al., 2012), kidney, brain (Salih et al., 2018), testis (Dias et al., 2015; Ahmed, 2016), pancreas and fundus of stomach (Ayuob and ElBeshbeishy, 2016), gastric and duodenal mucosae (Mohamed et al., 2018).

These lesions could be attributed to imbalance of oxidant/antioxidant environment in these tissues with increased oxidant stress as a result of the production of reactive oxygen species (Ayuob and ElBeshbeishy, 2016). Reactive oxygen species (ROS) are likely involved in the pathogenesis of wide variety of human diseases. ROS are very harmful and may cause direct damage to vital cell constituents such as proteins, lipids, and deoxyribonucleic acid (DNA) (Ahmed, 2016).

An initial step in measuring liver damage is a simple blood biochemical test to evaluate

\section{IV-DISCUSSION}

the presence of certain liver enzymes in the blood. The activity of these enzymes is normally used to determine liver function. Under normal conditions, these enzymes reside within the hepatocytes. But when the liver is injured, these enzymes are spilled into blood stream. Also, liver damage causes an obstruction of normal bile flow from the liver to the small intestine results in elevated bilirubin. Elevation of the cellular enzymes in plasma or serum and elevation of bilirubin level give indication about the hepatic injury after consumption of energy drinks that is confirmed by histopathology (Gheith, 2017).

The results of the present study revealed a statistically significant increase in serum level of the studied liver function markers (AST, ALT, ALP, Total bilirubin) in power horse and red bull groups as compared to the control group.

These results were similar to Akande and Banjoko, (2011), Ebuehi et al., (2011), Khayyat et al., (2012), Ugwuja, (2014) and Mansy et al., (2017).

On the contrary, Schuchowsky et al., (2017) observed non significant change in the 
serum level of liver function markers and attributed this to amino acid taurine that presents in high concentration in energy drinks, which might, in the long term, have a protective effect through its antioxidant properties.

The data of the current study showed that power horse was more harmful than red bull in its action on liver enzymes. This result could be explained by Khayyat et al., (2012) who reported that the different action of the energy drinks could be attributed to the different mixture of their ingredients.

In the present study, the liver enzymes levels were reduced in the recovery period groups. This result was similar to Akande and Banjoko, (2011) indicating that the effect of EDs are reversible.

Also, the current study revealed that treatment with $\omega 3$ showed reduction in the serum level of liver enzymes and total bilirubin. This was in agreement with Meganathan et al., (2011).

The anti-inflammatory and/ or antioxidant effects of omega-3 fatty acids ( $\omega 3$ - FAs) through suppression of lipid peroxidation and scavenging of free radicals have been reported by Ernest and Magdalena, (2008). This anti-inflammatory property of $\omega 3$ - FAs is due to the action of eicosapentaenoic acid, which is one of the components of omega-3. The anti-inflammatory action is achieved by reducing the pro-inflammatory cytokines like intrleukin-1(IL-1) and tumor necrosis factor alpha (TNF $\alpha)$ (Asaad and Aziz, 2011), and through regulation of inflammatory gene expression (e.g. Nuclear Factor Kappa B) (Calder, 2009).

The total protein test is a rough measure of all the proteins found in the fluid portion of the blood. Its measurements can reflect nutritional status and may be used to screen for and help diagnose kidney disease, liver disease, and many other conditions. Low total protein levels can suggest a liver disorder, a kidney disorder, or a disorder in which protein is not digested or absorbed properly (Bassey et al., 2017).

The result of the current study revealed statistically high significant decrease in serum protein level in power horse and red bull treated groups.

This result could be explained by Gheith, (2017) who stated that EDs may do so through inhibition of A2A adenosine receptors, which accelerates the development of interstitial inflammation, augments proteinuria and reduces serum protein. In addition, the observed decrease in serum proteins could be attributed in part to the damaging effect of EDs on liver cells as confirmed by the increase in the activities of serum AST, ALT and histological changes (Attia and Nasr, 2009).

On the contrary, Ebuehi et al., (2011) reported an increase in serum protein after administration of EDs. They explained that on the basis that the EDs results in exacerbated dehydration via excessive diuresis with consequent hemoconcentration and increase in serum proteins.

Results of the present study showed that both recovery period and $\omega 3$ fatty acid resulted in increase in serum protein level with more increase in groups treated with $\omega 3$ fatty acid as compared to power horse and red bull groups. This result agreed with Attia and Nasr, (2009)

Results of the current study showed that power horse and red bull induced histopathological alterations in the hepatic cells. All hepatocytes were vacuolated with small darkly stained nuclei. Also, there were dilated and congested blood vessel and marked mononuclear cellular infiltration in portal tract area and the central vein appears congested.

This result is confirmed by Khayyat et al., (2012) who explained hepatic cytoplasmic vacuolations due to presence of lipid droplets which were attributed to deteriorative changes within hepatocytes.

Also, the current result is agreed with Kassab and Tawfik, (2018), who stated that These changes were a manifestation of cell damage and were caused by lipid peroxidation (oxidative stress) and DNA damage as a sign of toxicity and were attributed to the preservatives or caffeine gradient that are present in the energy drinks. 
Mansy et al., (2017) explained the congestion of blood vessels by microcirculatory disturbance that caused by energy drink intake. Also, Kassab and Tawfik, (2018) mentioned that ED had been associated with many cardiovascular disorders as well as increased platelet aggregation and impaired endothelial function. These findings were due to different reaction of taurine with caffeine present in the energy drink.

Ebuehi et al., (2011) disagreed with these histopathological results as they found no changes in hepatic tissue although presence of biochemical alterations. They explained this by the short time of exposure that is not enough to produce hepatic damage.

The present study showed that recovery period didn't induce improvement in hepatic tissue alterations. This may be due to the short recovery period (2 weeks) which is not enough to produce improvement in these alterations. This result agreed with Akande and Banjoko, (2011).

The results of this study revealed that treatment with $\boldsymbol{\omega} \mathbf{3}$ resulted in moderate improvement in the hepatic tissue.

This result was in accordance with Ayuob and ElBeshbeishy, (2016). Khanchandani, (2015) explained the ability of $\omega \mathbf{3}$ in protecting hepatic tissue through its anti-inflammatory effect by regulating tumor necrosis factor- $\alpha$ (TNF- $\alpha$ ) and elevating the immune system reaction.

\section{V-CONCLUSION}

Considering the results obtained from the present study it can be concluded that, the different energy drinks (power horse and red bull) induced biochemical and histological changes in the liver of adult male albino rats which were partially ameliorated by their withdrawal or co-administration of omega 3 fatty acids.

\section{VI-RECOMMENDATION}

On account of these toxicological findings, further researches and strict regulations on marketed energy drinks are needed.

\section{REFERENCES}

1 Abdou H. M. and Hassan M.A. (2014): Protective Role of Omega-3 Polyunsaturated Fatty Acid against Lead Acetate-Induced Toxicity in Liver and Kidney of Female Rats. Hindawi Publishing Corporation. BioMed Research International.; 2014 (435857):1-11.

2 Ahmed A. M. (2016): Expression of transcription factor NF KAPPA B/P65 and cyclooxygenase-2 $(\mathrm{COX}-2)$ in testicular damage induced by Red Bull energy drink in rat. International Journal of Advanced and Applied Sciences.; 3(10) : 49-56.

3 Akande I.S. and Banjoko O.A. (2011): Assessment of biochemical effect of Power Horse energy drink on hepatic, renal and histological functions in Sprague Dawely rats. Annu Rev Res Biol.; 1: 45-56.

4 Alabbad M. H., AlMussalam M. Z., AlMusalmi A.M., Alealiwi M.M., Alresasy A.I., Alyaseen H. N. and Badar A. (2019): Determinants of energy drinks consumption among the students of a Saudi University. J Family Community Med.; 26(1): 3644.

5 Asaad H. R. and Aziz F. M. (2012): Protective Role of Omega-3 Fish Oil against the Toxicity of Ifosfamide in Male Rats. Jordan Journal of Biological Sciences. ; 5(1): $37-46$.

6 Attia A.M. and Nasr H.M. (2009): Evaluation of protective effect of omega-3 fatty acids and selenium on paraquat intoxicated rats. Slovak J. Anim. Sci.; 42 (4): 180 - 187.

7 Ayuob N. and ElBeshbeishy R. (2016): Impact of an Energy Drink on the Structure of Stomach and Pancreas of Albino Rat: Can Omega-3 Provide a Protection?. PLoS ONE .; 11(2): e0149191.

8 Bassey N.O., Ekam V.S., Essien N.U. and Ekam N.V. (2017): Effect of Acetaminophen And Caffeinated Energy Drink on the Serum Protein Levels of Wistar Albino Rats During Sub-Chronic Alcohol Consumption. IOSR Journal of Biotechnology and Biochemistry (IOSR-JBB).; 3 ( 4): 35-38.

9 Bradford M.M. (1976): A rapid and sensitive method for the quantitation of microgram quantities of protein utilizing the principle of proteindze binding, Analit. Biochem.; 72: 248254.

10 Calder P.C. (2009): Polyunsaturated fatty acids and inflammatory processes: New twists in an old tale. Biochim.; 91(6):791-795.

11 Dias T.R., Alves M.G., Bernardino R.L., Martins A.D., Moreira A.C., Silva J. et al. (2015): Dosedependent effects of caffeine in human Sertoli cells metabolism and oxidative profile: relevance for male fertility. Toxicology.; 328: 12-20.

12 Ebuehi O.A., Ajayl O.E., Onyeulor A.L. and Awelimobor D. (2011): Effects of oral administration of energy drinks on blood 
chemistry, tissue histology and brain acetylcholine in rabbits. Nig Q J Hosp Med.; 21(1):29-34.

13 Emam H., Ahmed E., Abdel-Daim M. (2018): Antioxidant capacity of omega-3-fatty acids and vitamin E against imidacloprid-induced hepatotoxicity in Japanese quails. Environmental Science and Pollution Research.; 25(12):1169411702.

14 Ernest K.J.P. and Magdalena K. (2008): Fatty Acid Facts, Part III: Cardiovascular Disease, or, a Fish Diet is not Fishy. Drug News Perspect.;21(10):552-61.

15 Gheith I., (2017): Clinical Pathology of caffeinated and non-caffeinated energy drinks: Review. Life Science Journal 2017;14(9)P 21-36.

16 IFCC (1980): Colorimetric determination of GOT (AST) or GPT (ALT) activity. J. Clin. Chem. Clin. Biochem.;18: 521.

17 Kassab A.A. and Tawfiq S.M. (2018): Effect of a caffeinated energy drink and its withdrawal on the submandibular salivary gland of adult male albino rats: A histological and immunohistochemical study. Egyptian Journal of Histology (EJH). ;41(1): 11-26.

18 Keiding R., Hörder M., Denmark W. G., Pitkänen E., Tenhunen R., Strömme J. H. et al. (1974): Recommended methods for determination of four enzymes in blood. Scand. I. Clin. Lab. Invest.;33(4): 291- 306.

19 Khanchandani R. (2015): Role of omega-3 fatty acid in hepatoprotection against carbon tetra chloride induced liver injury in albino rabbits. J. Biomed Pharm Res.; 3:131-135.

20 Khayyat L., Sorour J., Al Rawi M. and Essawy A. (2012): Histological, Ultrastructural and Physiological Studies on the Effect of Different Kinds of Energy Drinks on the Liver of Wistar albino Rat. J American Science; 8 (8): 688-697.

21 Khayyat L., Essawy A., Sorour J. and Al Rawi M. (2014): Impact of Some Energy Drinks on the Structure and Function of the Kidney in Wistar Albino Rats. Life Science Journal;11(10): 11311138

22 Kieranan, J. A. (1999): “ Histological \& Histochemical Methods". 3rd ed., Oxoford University Press, London, New York, New Delhi.

23 Malinauskas B.M., Aeby V.G., Overton R.F., Carpenter-Aeby T. and Barber-Heidal K.A. (2007) : survey of energy drink consumption patterns among college students. NutrJ.; 6(35):17.
24 Mansy W., D. M. Alogaiel, M. Hanafi4, E. Zakaria (2017): Effects of chronic consumption of energy drinks on liver and kidney of experimental rats. Tropical Journal of Pharmaceutical Research.; 16 (12): 2849-56.

25 Meganathan M., Gopal M. K., Sasikala P., Mohan J., Gowdhaman N., Balamurugan K. et al. (2011): Evaluation of hepatoprotective effect of omega 3-Fatty Acid against paracetamol induced liver injury in albino rats. Global Journal of Pharmacology.; 5 (1): 50-53.

26 Mohamed R. A., Ahmed A. M., Al-Matrafi T. A., AlRoalle A. H., Alfayez M. A., Al-Okaiel D. M. , El Fouhil A. F., M. Atteya (2018): Energy drinks induce adverse histopathological changes in gastric and duodenal mucosae of rats. International Journal of Advanced and Applied Sciences.; 5(2): 81-89.

27 National Center for Complementary and Integrative Health (NCCIH) (2017): U.S. Department of Health \& Human Services, National Institutes of Health, USA. gov. 9000 Rockville Pike, Bethesda, Maryland 20892. Available at: https://nccih.nih.gov/health/energydrinks.

28 Salih A. N., Abdul-Sadaand I. H., Abdulrahman N. R. (2018): Histopathological Effect of Energy Drinks (Red Bull) on Brain, Liver, Kidney, and Heart in Rabbits. Medical Journal of Babylon.; 15 (1): $16-20$.

29 Schuchowsky E., Schaefer D., Salvador R. A., Nascimento A. E., , Til D., Senn A. P., and Amaral V. L. (2017): Effects of energy drinks on biochemical and sperm parameters in Wistar rats. Nutrire . ; 42(22): 1-7.

30 Seifert S., Schaechter J., Hershorin E. and Lipshultz S. (2011): Health effects of energy drinks on children, adolescents, and young adults. Pediatrics.; 127 (3): 511-528.

31 Soliman N.B.E., Kalleny N.K. and Abd El Samad A.A. (2010): Effect of omega-3 versus omega-6 fatty acids on induced ulcerative colitis in male albino rat. Light and electron microscopic study. Egyptian Journal of Histology.; 33:620-34.

32 Ugwuja I.E. (2014): Biochemical Effects of Energy Drinks Alone or in Combination with Alcohol in Normal Albino Rats. Advanced Pharmaceutical Bulletin, 2014, 4(1), 69-74.

33 Walter M. and Gerade H. (1970): A colorimetric method for determination bilirubin in serum and plasma. Micro Chem J.;15:231-236. 
دراسة التأثير الوقائى للأوميجا 3 علي التسمم الكبدى المحدث ببعض مشروبات الطاقة فى ذكور الجرذان البيضاء البالغة

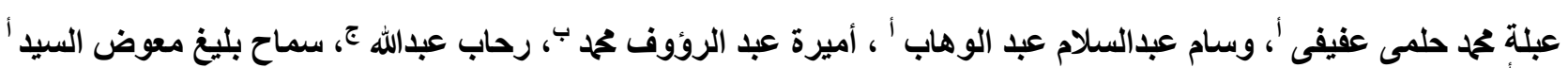

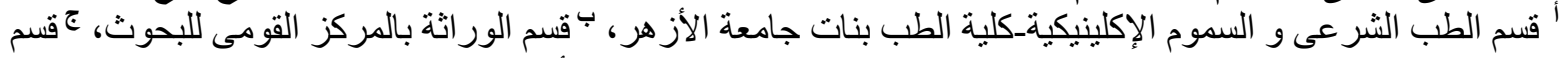

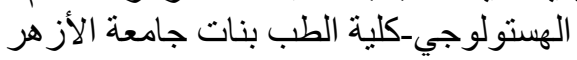

المقدمة:

لقد أصبحت مشروبات الطاقة ظاهرة عالمية وشعبية خاصة بين البالغين والثباب والكبد هومن أكثر الأعضاء تعرضًا

للسمية.

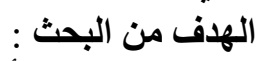

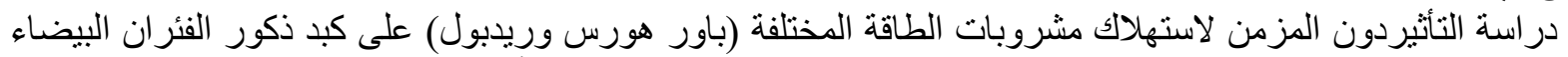

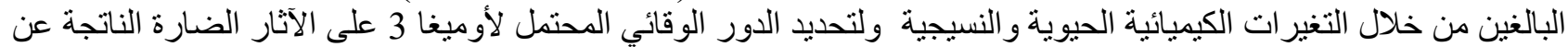

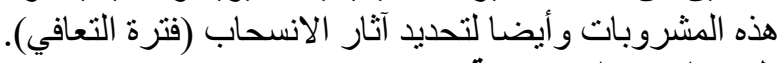

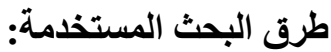

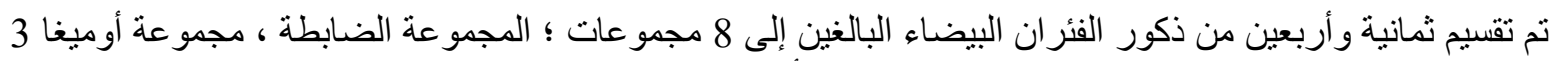

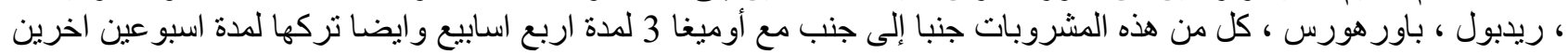

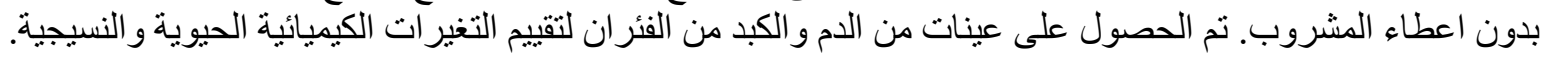
النتائج:

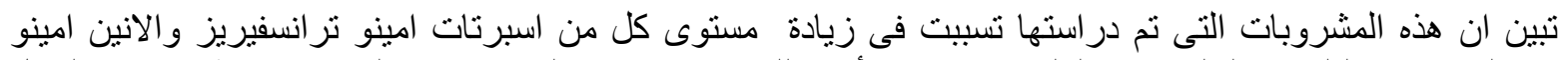

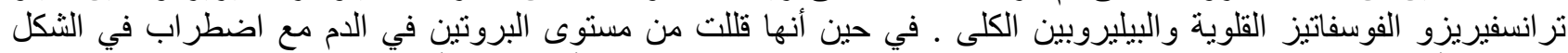

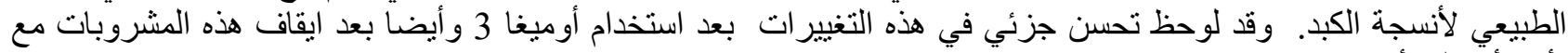
تأثنير أفضل لأوبل لأوميغا 3.

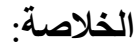

مشروبات الطاقة لها نأثير سام على الكبد قد تتحسن جزئيا بعد نوقف هذه المشروبات او بتناول الأوميغا3. التوصية: هنالك حاجة ماسة للسيطرة الصارمة على استهلاك مثل هذه المشروبات لما لها من اثار ضارة. 